\title{
Citizen participation in urban local government: a case study of Kanaighat Paurashava in Bangladesh
}

\section{Commonwealth Journal of Local Governance}

Issue 19: December 2016

http://epress.lib.uts.edu.au/ojs/index.php/cjlg

\author{
Mohammad Shahjahan Chowdhury \\ Department of Public Administration \\ Shahjalal University of Science and Technology \\ Bangladesh
}

\section{Muhammad Aktaruzzaman}

Department of Public Administration

Shahjalal University of Science and Technology

Bangladesh

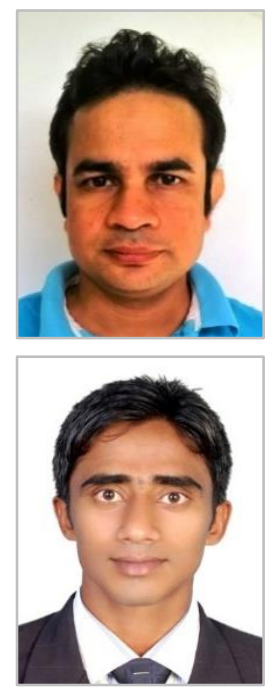

\begin{abstract}
Scholars have identified many variables as determinants of citizen participation, but not all of these are relevant to citizen participation in specific cultural and political contexts. This paper seeks to identify the specific factors which work as drivers for citizen participation in Bangladesh through a case study of Kanaighat Paurashava (municipality), an urban local government. It identifies the following variables which strongly affect citizen participation: the role of elected representatives, notably their willingness and awareness; the provision of information to citizens; citizens' capacity; and resources available. Findings also suggest that a holistic approach is needed to understand and change representatives' attitudes towards citizens and ensure participation.
\end{abstract}

Keywords: Citizen participation, local government, elected representative, citizens' capacity

\section{Introduction}

Citizen participation is a mechanism to guide local development and governance. There are various ways of involving citizens in the governance process, including providing information; enabling citizens to take part in decision-making, implementation or evaluation; and sharing benefits. The value of engaging citizens in local government is argued by many scholars (Barber 1984; Charlick 2001;

(C) 2016 Mohammad Shahjahan Chowdhury and Muhammad Aktaruzzaman. This is an Open Access article distributed under the terms of the Creative Commons Attribution 4.0 Unported (CC BY 4.0) License (https://creativecommons.org/licenses/by/4.0/), allowing third parties to copy and redistribute the material in any medium or format and to remix, transform, and build upon the material for any purpose, even commercially, provided the original work is properly cited and states its license. 
Patsias et al. 2013; Thomas 1995; Yang and Pandey 2011; Yang and Callahan 2007). Bherer (2010) mentions two main drivers for implementing citizen participation: (1) citizens' demand for participation; and (2) the presence of local leaders, elected officials and public servants who wish to open up political processes to citizens. However, other scholars argue that dialogue between voters and their elected representatives is limited. One reason cited is that elected positions are captured by political elites and power groups, while voters are placed at arms' length who only communicate with them through opinion polls or market research. A second reason cited is that citizens' influence is mainly through the voting system, while the outcomes are governed by public administrators - who have policy influence due to the rise of delegation and devolution, but who often lack grounded knowledge and may not be fully accountable for their decisions (Skelcher and Torfing 2010, p. 74).

Citizen participation has been characterised as necessary to ensure a good relationship with the public, better service quality and better decision-making - which in turn requires a shift in policy, budget and commitment (ODPM 2002). Moreover, citizen participation is thought to promote accountability, legitimacy, transparency and empowerment (Bohman 2005; Schillemans 2008). However, whether citizen participation actually brings these positive outcomes depends on related actors and factors.

Most studies on citizen participation focus on developed countries, not developing countries. The identification of key determinants in developing countries is important to ensure the active involvement of citizens and achieve positive outcomes. This paper offers a case study of Kanaighat Paurashava (municipality) in Bangladesh and looks at three key variables - elected representatives, citizens' capacity and resource availability - and their implications for participatory governance. The paper is structured as follows: firstly, a discussion of perspectives on citizen participation; secondly, the methodology and framework used; and finally, the authors' research findings and discussion, followed by conclusions.

\section{Perspectives on citizen participation}

There is agreement among scholars and practitioners of the value of citizen participation in a democratic polity. However, considerable disagreement and debate exist over the process, design, determinants and outcomes of, and barriers to, citizen participation - notably because cultural and political contexts vary widely across nations. For example, Agarwal (2001) identified five rungs in the ladder of participation, based on the degree of engagement from nominal to interactive; while other researchers have conceptualised participation as occurring on an institutional continuum from low (information-seeking) to high (interactive dialogue through a governance network) (Skelcher and Torfing 2010). These categorisations are not exhaustive, but they can help to identify levels and effectiveness of participation. In the South Asian context, Agarwal (2001) identified systemic factors (rules, norms, perceptions, and attributes) and their impacts on participation - or lack of it - in the areas of gender equity, empowerment and institutional efficiency. Taking a normative view in the European context, Skelcher and Torfing 
(2010) argue that the problem of democratic participation may be overcome through institutional means. Similarly, Lowndes et al. (2006) favour changes to institutional rules to shape participation, as these are seen as more malleable than resources and social capital, which cannot easily be changed.

This paper argues that neither institutional design/rules nor systemic factors alone can overcome the barriers to citizen participation. An institutional arrangement may not work due to other factors - for example the representation system. In a developing country like Bangladesh democratic values are not well established and local governance is no exception - although, perhaps paradoxically, turnout is high in both national and local government elections, thus avoiding one of the problems faced by representative democracy in many developed countries. Similarly, in Bangladeshi local government specific institutions, laws and rules do exist to promote citizen participation, but their impact is minimal due to other factors such as lack of citizen capacity. For example, although reserved seats for women are provided on councils, this is not a solution to exclusionary problems concerning gender. Also, a number of studies have examined citizen participation from an administrative perspective and find that organisational factors - such as political support, political control, leadership, red tape, hierarchical authority, mutual trust, citizenship education, technological knowledge, accessibility, infrastructure, training, budget and resource authority, and variables related to participants' competence and representativeness - all have strong impacts on participation outcomes (ODPM 2002; Yang and Callahan 2007; Yang and Pandey 2011; Aulich 2009; Bherer 2010).

Yang and Callahan (2007) identified the important 'actors' in citizen participation as being elected officials, government agencies, citizens, the local media and non-profit organisations. However, this analysis examined participation based on the views of executives of public organisations, ignoring citizens' and representatives' perspectives. The weakness of this approach is highlighted by the work of Copus (2010), which examined how representatives' attitude and willingness affect participation effectiveness. Using survey data, he found that most representatives like to enact measures that they and their parties believe are right, rather than measures which citizens demand. However, although his findings offer important insights, his analysis neglects other socio-economic-political and cultural variables, as well as the gender aspect. This is important as the predominance of male elected representatives is the key factor in determining participation and outcomes in developing countries like Bangladesh.

While these studies have identified many actors and factors affecting citizen participation, it is hard to specify which are the most crucial in a given social, political or cultural context. In addition, testing all factors simultaneously is expensive and strenuous. It is therefore useful to identify critical actors and factors, especially as doing so may lead to the strengthening of related actors and factors. For example, a strong representation system may lead to responsive leaders, who are well placed to influence organisational variables. Citizens' capacity (Verba et al. 1995) and resources (Aulich 2009; Rainnie 
2005) also have a powerful impact on other factors, including administrators and representatives (Charlick 2001). This suggests that unless citizens are capable of effective advocacy and adequate resources are available to local government, the road to participation will remain a difficult one. Some studies have ignored these factors, on the grounds that they are difficult to change. However, this paper argues that intervention on those factors is equally important, and there are many instances in Bangladesh where poor and illiterate people have been mobilised to become active citizens. Thus, to identify the principal actors and factors in citizen participation, a holistic approach from all three of citizens', representatives' and administrators' perspectives is needed.

The outcomes of participation are also disputed. On the one hand, some studies demonstrate that citizen participation has a number of positive impacts (e.g. Michels and Graaf 2010; Lombard 2013). On the other hand, other studies question the benefits of participation (Stewart 2006; Wiseman 2006). The study of Michels and Graaf (2010) in two municipalities of the Netherlands revealed that citizen participation has a wide range of positive outcomes, including increasing citizens' feelings of responsibility, encouraging people to listen to diverse opinions, and enhancing the legitimacy of decision-making. However, they note that women, the young, poorly educated people and minority groups were under-represented, albeit without identifying why. Similarly, Lombard (2013) found that a long tradition of autonomous participation and collective action means that Mexico has a relatively participant-oriented urban local government system, in contrast to many other cultural contexts where governments are struggling to motivate people to participate in local government. As a result, citizens make their demands, and local governments provide services through participatory processes. Public representatives are now more involved in rural development projects and citizens participate in projects through various means such as bearing costs, donating items in kind, and volunteering (Waheduzzaman 2010). In contrast, however, a study of participatory engagement in Australia by Wiseman (2006) concludes that the benefits - strengthening the social bond and engagement - are exaggerated and that participation has not been successful due to structural inequality and injustice. The present paper adds to the debate by arguing a further point of view. Using the framework developed by Michels and Graaf (2010) on citizen participation and democracy, it finds that citizen participation does not necessarily bring democratic outcomes in terms of inclusion, civic skill and virtue, deliberation or legitimacy.

Studies have identified a range of barriers to effective participation, including lack of citizens' time, lack of trust in government, lack of information, lack of expertise, inadequate government-citizen communication, poorly defined objectives, and the exclusion of some social groups due to social segmentation by law. Participation is also burdensome and unequal for people who are living with low incomes (Yang and Callahan 2007; Lombard 2013; Agarwal 2001). Moreover, government staff and public representatives may hinder citizen participation because these actors may fear their irregularities may come to light (Waheduzzaman 2010). All these observations suggest that the barriers are context- 
specific and relate to all three of the areas discussed above: the representation system, citizens' capacity and resources.

This paper tries to be realistic and explore the present scenario of participation in urban local government in Bangladesh. It asks: Which factors are most salient in ensuring citizen participation in urban local governments in a developing country like Bangladesh? Have participation initiatives brought positive outcomes? And finally, what are the barriers to effective participation?

\section{Methodology and framework}

A case study methodology was applied to study citizen participation in urban local government, using Kanaighat Paurashava as the subject. Kanaighat Paurashava was chosen as a fairly typical urban local government body in Bangladesh. Established as an administrative area on 25 October 2005, it is situated within Kanaighat Upazila $^{1}$ in the Sylhet District. It has a land area of around 4,700 acres, which encompasses nine wards, 23 moujas (mouza is the lowest revenue collection unit) and 31 villages. It has a population of 27,078 (Bangladesh Bureau of Statistics 2011), of which 12,793 are voters.

In Bangladesh, there are two tiers of urban local government: municipal corporations (city corporations) in large cities, and municipalities (paurashava) in small cities and towns. The local government system follows a 'dual supervision model' inherited from British colonial rule, where centrally appointed officials play a strong role alongside sectoral and functional ministries in providing local services (Shah and Shah 2006).

This study explored the scope for citizen participation in the development process of paurashava, including planning, decision-making, budgeting, monitoring and evaluation. The study also examined whether the participation process in paurashavas is passive or active, using the framework set by Michels and Graaf (2010). The framework is developed from the theories of participatory democracy, deliberative democracy and social capital. These theories claim that citizen involvement has positive impacts on democracy, which ensure the inclusion of citizens in the policy process and the development of civic skills and civic virtues. It is held that this leads to rational decisions based on the public voice and increases the legitimacy of the process and the outcome (Michels and Graaf 2010, p 481). Finally, the study investigated which actors and factors are the most critical in influencing citizen participation in the Bangladeshi context.

The target respondents for the study were citizens, elected representatives, government officials, community leaders and stakeholders in the Kanaighat Paurashava. The sample size was 50 and a

\footnotetext{
${ }^{1}$ An upazila is the lowest administrative unit where government officials work as central government agents. Both rural (upazila parishad) and urban (paurashava) local governments also exist in an upazila. The upazila parishad (council) is the second tier of rural local government and the paurashava is the lowest tier of urban local government in Bangladesh.
} 
purposive sampling method was used to select representative respondents (Table 1). Data were collected through surveys and in-depth interviews with key informants, allowing quantitative data to be supported by qualitative data.

Table 1: Categories of respondents

\begin{tabular}{|l|c|}
\hline Respondents & $\mathbf{N}=\mathbf{5 0}$ \\
\hline Citizens & 30 \\
Ordinary citizens & 05 \\
Stakeholders & 05 \\
Community leaders & \\
\hline Representatives & 01 \\
Mayor & 04 \\
Councillors (general seats) & 02 \\
Women councillors (reserved seats) & 03 \\
\hline Government (mid-level) officials & 03 \\
\hline
\end{tabular}

Source: Field data, collected from the Kanaighat Paurashava area, August 2013

The elected representatives are mayors and councillors. They also act as local political leaders as many of them are involved in party politics. The stakeholders are identified as those citizens whose interests are directly affected by paurashava activities. Community leaders are people who are not elected, but nevertheless have an influential voice in paurashava activities. Citizens are the voters and residents of the paurashava.

Respondents were contacted by the authors personally, and the objective of the study was explained. Respondents were given assurances of anonymity, privacy and confidentiality. Those who agreed to provide information were interviewed using a semi-structured interview schedule.

Respondents were asked about their participation in development planning, decision-making, project implementation, monitoring and evaluation. They were also asked whether they felt their participation was effective enough to bring positive results. Finally, they were asked what, if any, obstacles they encountered in participating in local government.

The paper then analysed its findings based on the three themes outlined above: attitudes of elected representatives, citizens' capacity and resource availability. These themes were selected based on background research and in-depth interviews with research participants.

\section{Findings and discussion}

\section{Elected representatives}

Elected representatives are important actors in the process of citizen participation. Copus (2010) argues that the way in which councillors view citizen participation has an impact on its effectiveness. Eulau et al. (1959, p. 742) categorised representatives into three types - delegates, trustees and politicos (politicians) - to illustrate how representatives operate within a governance network. According to this typology, delegate leaderships work based on local people's opinion, trustee leaderships work based on their own judgement and 'politico' leaderships combine the two. In Bangladesh, the majority of leaders 
fall in the 'trustee' category as they like to go their own way, ignoring public opinion. They believe that engaging citizens would constitute a threat to them, and hence they are not interested in ensuring citizen participation or providing data on participation. Bangladesh is not alone in this. Even in a developed country like the United Kingdom (UK), councillors are sceptical about citizen participation. They think themselves more knowledgeable than the general public. For example, Copus cites the following comment from a councillor in the UK:

Local government is complex and difficult and we have access to information and advice that the public doesn't have. You just can't go around asking people what they think; it's not that easy; people don't have the knowledge or information to make sensible decisions (Copus 2010, p. 584).

Another study in the UK found that citizens are deterred from participation by negative attitudes within the council, lack of information on opportunities to participate, and a belief that the council will not respond to their concerns (ODPM 1998). Similarly, a study of United States local government found that:

Meaningful participation is rarely found, as many public officials are reluctant to include citizens in decision-making, or if they do, they typically involve citizens after the issues have been framed and decisions have been made (Yang and Callahan 2007, p. 249).

In situations such as these, citizen participation may turn into passive or nominal participation, and this was found to be the case in Kanaighat Paurashava. Structural factors also affect citizen participation. Skelcher and Torfing (2010) argue that institutional designs (which they identify as rules, laws, procedures and norms) enable or constrain actors' agency in participation.

Within Kanaighat Paurashava, there is some scope for people to participate in development activities. Paurashavas do have a legal framework to ensure citizen participation, under sub article 122 of Article 58 in Bangladesh's Local Government (Paurashava) Act 2009 (Government of Bangladesh 2009). This mandates that paurashavas should ensure citizen participation through a range of different committees. However, many elected representatives, government officials and citizens are unaware of this provision, mainly because they are not fully informed or well trained (Table 2). If representatives are not aware of their legal responsibilities, then it is hardly surprising if citizens do not participate in development activities.

This issue can be examined in Kanaighat Paurashava using the example of participatory budgeting. This process has been advocated as a medium for empowering citizens to strengthen their voice and promoting transparency and accountability (Cabannes 2014). Opportunities for citizen participation in the budget-making process do exist in Kanaighat Paurashava (Table 2), as the paurashava annual budget is generally published in June in the presence of the general public, local leaders, journalists, political leaders and other local opinion-formers. Additionally, public input is sought during the budget planning process. However, the attitude of one of the elected representatives towards this process tends to be negative, for example: 
I think there is no need for the ordinary citizen to take part in the budget-making process. You know many men means many minds. So it will be better if they don't participate in this process (elected male representative, interview 13, June 2013).

Similarly, with regard to citizen participation, each paurashava is supposed to have two committees: a Town-Level Coordination Committee (TLCC) and a Ward-Level Coordination Committee (WLCC). The TLCC has 50 members, including the mayor and other councillors, and is responsible for organising regular open public meetings in the paurashava. This committee is mandated to encourage citizens to participate through discussion and sharing of views. Its remit is to look after the overall condition of the municipality. The WLCC in principle has 11 members, including the female councillor of each ward, with one of the ward councillors as its chairman. This committee is mandated to ensure citizen participation in every ward. However, in practice, the study found that such committees were not constituted.

Among those respondents who were representatives and officials, three claimed there was a coordination committee, another three said there was no such committee, and the rest did not want to comment (Table 2). The respondents who provided positive answers were unable to give any specifics such as the structure, composition or functions of the committee. Notably, it was observed that the chief executive was unable to say anything about either committee, as they were not functional.

Table 2: Opinion of respondents (representatives and officials) as to existence of participation frameworks: legal requirement, coordination committees, scope for participatory budgeting

\begin{tabular}{|l|c|c|c|}
\hline Opinion & $\begin{array}{c}\text { Statute in paurashava's } \\
\text { legal framework } \mathbf{N}=\mathbf{1 0}\end{array}$ & $\begin{array}{c}\text { Coordination committees } \\
\text { (TLCC and WLCC) } \mathbf{N = 1 0}\end{array}$ & $\begin{array}{c}\text { Scope for participation in } \\
\text { budgeting } \mathbf{N = 1 0}\end{array}$ \\
\hline Yes & 04 & 03 & 09 \\
\hline No & 03 & 03 & 01 \\
\hline No comments & 03 & 04 & 0 \\
\hline
\end{tabular}

Source: Field data, collected from the Kanaighat Paurashava area, August 2013

Additional provisions exist to form different standing committees such as law and order and public security, accounts and audit, communication and infrastructure, urban planning and development, and women and children's committees. These committees are supposed to perform a range of functions. When asked about standing committees in the paurashava, six out of the 10 respondents had no knowledge of them (Table 3). The standing committees in principle comprise five members from among councillors and are open to the public:

If any expert person or any citizen or citizens expresses interest to be present at any meeting, municipal or standing committee or other, any committee can permit him to be present and he can raise his opinion. The committee can take a decision or make a suggestion according to his opinion (Local Government (municipality amendment) ordinance 2010, p. 31).

However, it was observed that these committees exist only in legal documents and are not effective. 
Table 3: Opinion of respondents (representatives and officials) as to existence of standing committees in Kanaighat Paurashava

\begin{tabular}{|l|c|}
\hline Standing committees & $\mathbf{N}=\mathbf{1 0}$ \\
\hline No knowledge of committees & 06 \\
\hline $\begin{array}{l}\text { Law and order and public security, accounts and audit, communications and infrastructure, } \\
\text { urban planning and development, women and children's committees }\end{array}$ & 03 \\
\hline Bid committee, finance committee, hut-bazar (market) development committee & 01 \\
\hline
\end{tabular}

Source: Field data, collected from the Kanaighat Paurashava area, August 2013

Among citizen respondents, 27 out of 40 citizens said they did not participate in the planning process at Kanaighat Paurashava as they were not informed about it. When it came to decision-making, 36 out of 40 respondents did not participate, while 23 out of 40 did not participate in the implementation, monitoring or evaluation of any development activities (Table 4). It appears that either citizens are not invited to participate, or they do not know where and how development projects are planned, even though they are willing to participate (Table 4). Among those who did participate in development projects, seven participated in road construction, six in market development and two in the establishment of a primary school (Table 5).

Table 4: Participation of respondents (citizens) in development projects

\begin{tabular}{|l|c|c|c|}
\hline $\begin{array}{l}\text { Participation } \\
\mathbf{N}=\mathbf{4 0}\end{array}$ & Planning & Decision-making & $\begin{array}{c}\text { Implementation, } \\
\text { monitoring and evaluation }\end{array}$ \\
\hline Yes & 13 & 04 & 17 \\
\hline No & 27 & 36 & 23 \\
\hline Reasons behind no answer & $\mathrm{N}=27$ & $\mathrm{~N}=36$ & $\mathrm{~N}=23$ \\
\hline No one informed me & 27 & 36 & 21 \\
\hline Unwillingness to participate & 0 & 0 & 0 \\
\hline Other reasons & 0 & 0 & 02 \\
\hline
\end{tabular}

Source: Field data, collected from the Kanaighat Paurashava area, August 2013

Table 5: Types of development project participated in by respondents (citizens)

\begin{tabular}{|l|c|}
\hline Activities & $\mathbf{N}=\mathbf{1 7}$ \\
\hline Road construction & 7 \\
\hline Market development & 6 \\
\hline Establishment of primary school in paurashava & 2 \\
\hline Other development activities & 2 \\
\hline
\end{tabular}

Source: Field data, collected from the Kanaighat Paurashava area, August 2013

From the above discussion, some conclusions can be drawn. First, because elected representatives are not interested in engaging citizens in local government, they do not provide information on participation. In cases where they do inform the local community, people do not get an opportunity to be heard on the issues under discussion. As a consequence, the level of participation in the paurashava is perceived by citizens to be low (Table 6). 
Table 6: Citizen respondents' views on their level of participation

\begin{tabular}{|l|c|}
\hline Views & $\mathbf{N}=\mathbf{4 0}$ \\
\hline Very good & 01 \\
\hline Good & 14 \\
\hline Poor & 20 \\
\hline Very poor & 05 \\
\hline
\end{tabular}

Source: Field data, collected from the Kanaighat Paurashava area, August 2013

As one respondent puts it:

I had a strong intention to speak, but nobody called on me. So I did not participate in the decision-making process of our paurashava (citizen, interview 7, June 2013).

Elected representatives see themselves as the sole actors in local development. They do not attach importance to citizen engagement, as they think people lack the skills to participate in council activities. They also believe people are cynical and will hinder development activities (Waheduzzaman 2010). Furthermore, they see themselves as patrons and citizens as their clients; and as leaders they are not interested in educating and engaging citizens in the development process, because this could mean their mistakes and self-interest come to light. One respondent explained:

The mayor or councillors have never invited us to join in the planning process of any development activities, even if we want to participate voluntarily; they don't disclose their plan to us (community leader, interview 4, June 2013).

Another respondent said:

We are common people. We are valuable when an election comes. We elect our representatives through an election; afterwards they become our boss. They do not create any opportunity for us to participate in the planning of paurashava activities (stakeholder, interview 5, June 2013).

\section{Citizens' capacity}

The success of participation also depends on citizens' capacity as stakeholders in terms of education, wealth and civic skills (Pattie et al. 2004; Skelcher and Torfing 2010). Verba et al. (1995) in their SES (socioeconomic status) model argued that people with higher socioeconomic status (money, education and civic skills) are more active in politics. Similarly, Skelcher and Torfing (2010) argue that large inequalities in education and wealth often make it extremely difficult to ensure equal participation and influence. As another researcher notes: "The very fact of providing mechanisms and spaces of participation may become a burden for some people rather than an opportunity, especially when the burden is predominantly placed on communities which are already multiply disadvantaged" (Blakeley 2010, p. 139).

Hence even if participation increases it may not include all relevant and affected sections of society. Many people in Bangladesh are not educated enough to participate in the activities of local government. According to the Bangladesh Bureau of Statistics, in 2011 the adult literacy rate in Bangladesh was $58.3 \%$ (male $63.1 \%$ and female 53.5\%); in Kanaighat Paurashava it was even lower, at just $43.5 \%$ (male 
$45.8 \%$ and female $41.4 \%$ ). As a result, people do not know how to participate and do not get adequate information from government and local authorities. One respondent stated:

This is the mayor's or other representative's job; what is my business in their works? And they will not allow me to join in their functions (citizen, interview 6, June 2013).

It is also the case that affluent people with political power can more easily participate in planning processes. Party affiliation plays a significant role in this regard, as supporters of political parties get more opportunity to participate than citizens. Poor people are also prevented from participating because they lack opportunities to be heard. One respondent pointed out that:

Participation in the planning process is only for those who occupy a high socio-cultural background and have political power. We are poor and we have no political power. So we have no right to participate (citizen, interview 9, June 2013).

Another respondent noted that:

I am poor. Never have I directly been informed about any development activities of the paurashava, I know only through the mass media and public conversation, but can't participate; we are neither rich nor politically influential. So who will ask us? (citizen, interview 10, June 2013).

An additional problem is that the rules and regulations for participation are too complex for ordinary people to understand. This makes them fear participation, as this opinion indicates:

No, this participation could bring problems for me. I don't want to touch government money, because if I participate, people will blame me (citizen, interview 16, June 2013).

Citizens' capacity is also affected by gender, as women are one of the most disadvantaged sections of society in Bangladesh. Khan et al. (2007) emphasised that understanding and intervening in local culture is the key to improving social capital, using a participatory development model. They identified religious clerics (who are almost invariably male) as a barrier to women's engagement in development activities. The clerics obstruct female participation because of their religious dogma. They explain religious values wrongly in a way which favours patriarchy. Similarly, Drechsler and Jutting (2010) argue that the mindset of people in patriarchal societies is another important factor which impairs women's agency. Such attitudes, based on prevailing norms and traditions, are impediments to women's advancement. The studies above are based on research carried out in Algeria and Afghanistan. However, the observations are also true of Bangladesh and specifically of Kanaighat Paurashava. As one female respondent put it:

I, participate? (smiles) I am female! Who will inform me? Am I rich? Have I any value? Participation is only for those who have a lot of money and influence on us (female citizen, interview 17, June 2013).

\section{Resource availability}

Local government needs adequate resources to ensure citizen participation. Bangladeshi local governments are financially dependent on central government grants, which provide about $60 \%$ of their total revenue (Chowdhury and Al-Hossienie 2012). These grants are for specific purposes and local governments cannot choose how to spend them. However, resource problems are also prevalent in 
developed countries like the UK and Australia (Aulich 2009). Kanaighat Paurashava's annual revenue is TK4,000,000 (equivalent to US\$50,000), but this study found that neither the government nor the paurashava allocates any funds to ensure citizen participation. Instead, elected representatives are expected to collect 'own income' funds from within the paurashava. However, they are typically unwilling to collect such funds, as they think that if they impose taxes on residents they will lose public support in future elections.

\section{Outcomes of participation}

\section{Responsibility, legitimacy and civic skills}

This study observed that in Kanaighat Paurashava participation did not increase feelings of responsibility, confidence in the quality and legitimacy of decision-making, or civic skills. As a consequence, citizens tended to lose interest in participation. As one respondent stated:

I was invited to take part in decision-making and I was present at the meeting. But I observed that it was held only to inform us that a project is to be undertaken. After that the meeting was closed. That's my participation. Isn't it a mockery of us? (stakeholder, interview 2, June 2013).

Another respondent said:

I was present at a meeting where it was planned to prepare a football stadium in the paurashava. But I could not express my opinion. From that time, I promised that I will never participate in such types of staged meetings (community leader, interview 3, June 2013).

Another commented that:

I participated, it's true, but there was no consideration of my own demand and opinion. The authority has just run their projects as they see fit. Is it participation? What do you think? (citizen, interview 9, June 2013).

\section{Inclusion}

Moreover, as most elected representatives are not well educated, they are unaware of the benefits of engaging citizens and welcoming their contribution to the development process. Their opinions are also often contradictory in this regard. One representative asserted that:

We plan the development projects at the paurashava meetings in the presence of citizens. We always try to ensure citizen participation through the lifecycle of a project (elected male representative, interview 13, June 2013).

Nevertheless, elected representatives also think that the opportunity for citizens to participate in local government activities flows through them. This suggests that they do not value citizen participation. As another representative said:

Local people are participating in local programmes through their elected representatives (elected male representative, interview 12, June 2013). 
The above statement is supported by findings from the female elected representatives, as paurashava activities are dominated by male representatives. One female representative stated that:

I am a public representative. Most of the time I don't know how or where annual development projects are prepared. We are not consulted. How can citizen consultation be expected? (elected female representative, interview 14, June 2013).

Most female elected representatives in the paurashava face obstacles to participation because of male domination. They are not treated equally and their views are not taken into account. One female representative commented:

Equal opportunity, what do you mean? We are like a showpiece. Our views are not valued. Sometimes we are not informed about meetings, but we have to attach our signature in the registrar book later. We are just for formalities. We don't want this (elected female representative, interview 17, June 2013).

Another said:

We are women. We have no power. We are unable to express our opinion in a decisionmaking meeting independently or, if we express our opinion, it is never taken into account. We feel shame due to these sorts of behaviours. That is our main problem (elected female representative, interview 18, June 2013).

In addition, participation arrangements are made by the male representatives, and they tend to invite those citizens with whom they have close ties and who are influential. Consequently the poor, women and people with little education are rarely included. Even one official alluded to this:

We have a strong citizen participation mechanism in the paurashava's development programmes. But sometimes the practice of citizen participation is found to be manipulated by the local political leaders (government official, interview 11, June 2013).

\section{Conclusion}

Citizen participation is a mechanism for local government democratisation. The quality of democracy depends on how far people can participate in and influence the governance process. As local government is an important democratic force at grassroots level, facilitating citizen participation will strengthen democracy. Initiatives therefore need to be taken to engage citizens in the governance process. However, these initiatives tend to be limited due to a lack of commitment from elected representatives, citizens' capacity, and resource availability and allotment.

In Kanaighat Paurashava it was found that citizen participation is hampered by a number of factors. Firstly, elected representatives are not committed to participation. They are unwilling to provide information to people on its scope, and in some cases they involve only those citizens who are influential and have a close tie with them. They also lack knowledge on the legal and instrumental aspects of citizen participation in urban local government. There do exist institutional frameworks for engaging citizens in Kanaighat Paurashava's activities, but these are typically not successful due to elected representatives' lack of interest. Secondly, citizens' lack of capacity has a great impact on participation. Citizens are deterred from participation due to their socioeconomic vulnerability and lack of political 
power, and in particular the mindset of male representatives towards women is hampering equal opportunity for participation. Finally, availability of resources is an important determinant of participation in local government. Unfortunately in the case of Kanaighat Paurashava there is no resource allocation in this respect.

As citizen participation is critical for democratic decision-making and ensuring transparency and accountability, the factors mentioned above need to be addressed in a planned manner to achieve these outcomes. Leadership training is important to change mindsets and develop positive attitudes and skills among elected representatives. In addition, citizens' capacity can be increased through building awareness and changing orientation toward local government to encourage spontaneous participation. Last but not least, proper allocation and use of resources are also crucial for the successful implementation of participatory mechanisms.

\section{References}

Agarwal, B. (2001) Participatory exclusion, community forestry and gender: An analysis for South Asia and a conceptual framework. World Development, 29 (10), 1623-1648. doi: https://doi.org/10.1016/S0305750X(01)00066-3

Aulich, C. (2009) From citizen participation to participatory governance. Commonwealth Journal of Local Governance, 2, 44-60. doi: https://doi.org/10.5130/cjlg.v0i2.1007

Bangladesh Bureau of Statistics. (2011) Statistical pocketbook of Bangladesh 2010. Dhaka: Government of Bangladesh.

Bangladesh National Assembly. (2010) Ordinance no. 52 of 2010. Bangladesh Gazette.

Barber, B.R. (1984) Strong democracy: Participatory politics for a new age. Berkeley: University of California Press.

Bherer, L. (2010) Successful and unsuccessful participatory arrangements: Why is there a participatory movement at the local level? Journal of Urban Affairs, 32 (3), 287-303. doi: https://doi.org/10.1111/j.1467-9906.2010.00505.x

Blakeley, G. (2010) Governing ourselves: Citizen participation and governance in Barcelona and Manchester. International Journal of Urban and Regional Research, 34 (1), 130-45. doi: https://doi.org/10.1111/j.1468-2427.2010.00953.x

Bohman, J. (2005) From demos to demoi: Democracy across borders. Ratio Juris, 18 (3), 293-314. doi: https://doi.org/10.1111/j.1467-9337.2005.00300.x

Cabannes, Y. (2014) Contribution of participatory budgeting to provision and management of basic services: Municipal practices and evidence from the field. Working Paper. London, UK: International Institute for Environment and Development.

Charlick, B.R. (2001) Popular participation and local government reform. Public Administration and Development, 21 (2), 149-157. Available at: http://onlinelibrary.wiley.com/doi/10.1002/pad.155/epdf [Accessed December 2016]. doi: https://doi.org/10.1002/pad.155

Chowdhury, M.S. and Al-Hossienie, C.A. (2012) Quest for an effective and efficient local government: Local government in Japan and policy implication for local government in Bangladesh. Lex Localis - Journal of Local Self-Government, 10 (3), 247-264.

Copus, C. (2010) The councillors: Governor, governing, governance and the complexity of citizen engagement. The British Journal of Politics and International Relations, 12, 569-589. doi: https://doi.org/10.1111/j.1467-856X.2010.00423.x 
Drechsler, D. and Jutting, J. (2010) Why is progress in gender equality so slow? An introduction to the 'Social Institutions and Gender' Index. In: Chant, S. (ed) The international handbook of gender and poverty (pp. 77-83). UK and USA: Edward Elgar.

Eulau, H., Whalke, J., Buchanan, W. and Ferguson, L. (1959) The role of the representative: Some empirical observations on the theory of Edmund Burke. American Political Science Review, 53 (3), 742-756. doi: https://doi.org/10.2307/1951941

Government of Bangladesh. (2009) Paurashava Act 58, (Extraordinary Gazette of October 6, 2009), Government of the People's Republic of Bangladesh. Dhaka, Bangladesh: Bangladesh Government Press.

Khan, S.R., Rifaqat, Z. and Kazmi, S. (2007) Harnessing and guiding social capital rural development. New York: Palgrave Macmillan. doi: https://doi.org/10.1057/9780230609723

Lombard, M. (2013) Citizen participation in urban governance in the context of democratization: Evidence from low-income neighborhoods in Mexico. International Journal of Urban and Regional Research, 37 (5), 135-150. doi: https://doi.org/10.1111/j.1468-2427.2012.01175.x

Lowndes, V., Pratchett, L. and Stocker, G. (2006) Local political participation: The impact of rules-in-use. Public Administration, 84 (3), 539-561. doi: https://doi.org/10.1111/j.1467-9299.2006.00601.x

Michels, A. and Graaf, L.D. (2010) Examining citizen participation: Local participatory policy-making and democracy. Local Government Studies, 36 (4), 477-491. doi: https://doi.org/10.1080/03003930.2010.494101

Office of the Deputy Prime Minister (ODPM) (1998) Enhancing public participation in local government. Available at:

http://webarchive.nationalarchives.gov.uk/20120919132719/http://www.communities.gov.uk/documents/ localgovernment/pdf/156114 [Accessed December 2016].

Office of the Deputy Prime Minister (ODPM) (2002) Public participation in local government: A survey of local authorities. London: Demelza Birch, Local and Regional Government Research Unit, Office of the Deputy Prime Minister

Patsias, C., Latendresse, A. and Bherer, L. (2013) Participatory democracy, decentralization and local governance: The Montreal participatory budget in the light of 'empowered participatory governance'. International Journal of Urban and Regional Governance, 37 (6), 2214-30.

Pattie, C., Seyd, P. and Whiteley, P. (2004) Citizenship in Britain. Cambridge: Cambridge University Press.

Rainnie, A. (2005) Regional development policy and social inclusion. In: Smyth, P., Reddel, T. and Jones, A. (eds) Community and local governance in Australia (pp. 131-148). Sydney: UNSW Press.

Schillemans, T. (2008) Accountability in the shadow of hierarchy: The horizontal accountability of agencies. Public Organization Review, 8 (2), 175-194.

Shah, A. and Shah, S. (2006) The new vision of local governance and the evolving roles of local governments. In: Shah, A. (ed) Local governance in developing countries (pp. 1-46). Washington DC: The World Bank.

Skelcher, C. and Torfing, J. (2010) Improving democratic governance through institutional design: Civic participation and democratic ownership in Europe. Regulation \& Governance, 4 (1), 71-91 doi:10.1111/j.1748-5991.2010.01072.x http://onlinelibrary.wiley.com/doi/10.1111/j.17485991.2010.01072.x/pdf [Accessed August 2012].

Stewart, K. (2006) Designing good urban governance indicators: The importance of citizen participation and its evaluation in Greater Vancouver. Cities, 23 (3), 196-204.

Thomas, J.C. (1995) Public participation in public decisions: New skills and strategies for public managers. San Francisco: Jossey-Bass.

Verba, S., Schlozman, K. and Brady, H. (1995) Voice and equality: Civic voluntarism in American politics. Cambridge: Harvard University Press.

Waheduzzaman (2010) People's participation for good governance: A study of rural development programs in Bangladesh. PhD Thesis, Victoria University. Available at: http://vuir.vu.edu.au/16003/1/Thesis_3619041_Waheduzzaman.pdf [Accessed August 2012]. 
Wiseman, J. (2006) Local heroes? Learning from recent community-strengthening initiatives in Victoria. Australian Journal of Public Administration, 65 (2), 95-107.

Yang, K. and Callahan, K. (2007) Citizen involvement effort and bureaucratic responsiveness: Participatory values, stakeholder pressures and administrative practicality. Public Administration Review, 67 (2), 249264.

Yang, K. and Pandey, S.K. (2011) Further dissecting the black box of citizen participation: When does citizen involvement lead to good outcomes? Public Administration Review, 71 (6), 880-892. Available at: http://onlinelibrary.wiley.com/doi/10.1111/j.1540-6210.2011.02417.x/epdf [Accessed December 2016]. 